\title{
COMPOSITION, STRUCTURE AND DIVERSITY OF SHRUBLANDS in Central Nuevo LeOn, MeXico
}

\author{
Eduardo Alanís-Rodríguez ${ }^{1,5}$, Javier Jiménez-Pérez ${ }^{1}$, Humberto González-Rodríguez'1 \\ Pamela A. Canizales-Velázquez ${ }^{1}$, Arturo Mora-Olivo², José M. Mata Balderas ${ }^{3}$, \\ JaVier HeRnÁndez Salas ${ }^{4}$ \\ ${ }^{1}$ Facultad de Ciencias Forestales, Universidad Autónoma de Nuevo León, Linares, Nuevo León, Mexico \\ ${ }^{2}$ Instituto de Ecología Aplicada, Universidad Autónoma de Tamaulipas, Ciudad Victoria, Tamaulipas, Mexico \\ ${ }^{3}$ Gestión Estratégica y Manejo Ambiental, S.C., Apodaca, Nuevo León, Mexico \\ ${ }^{4}$ Facultad de Ciencias Agrícolas y Forestales, Universidad Autónoma de Chihuahua, \\ Ciudad Delicias, Chihuahua, Mexico \\ ${ }^{5}$ Author for correspondence: eduardo.alanisrd@uanl.edu.mx
}

\begin{abstract}
The aim of this study was to carry out a comparative analysis at the plant community level of the five most common types of shrublands (semithorn shrubland, microphyllous desert shrubland, rosetophyllous desert shrubland, piedmont scrub, and tamaulipan thornscrub) in the state of Nuevo Leon (northeastern Mexico). Twenty-five sampling sites (100 $\mathrm{m}^{2}$ each one) were established in each shrubland type (125 in total) to evaluate the vegetation structure. At each sampling site, we estimated the plant density $\left(\mathrm{N} \mathrm{ha}^{-1}\right)$, plant coverage $\left(\mathrm{m}^{2} \mathrm{ha}^{-1}\right)$, specific richness $(S)$, and alpha diversity index $\left(H^{\prime}\right)$. One way-analysis of variance was used to compare plant attributes between the plant communities. In the studied five plant communities, a total of 85 vascular plant species were registered, belonging to approximately 65 genera and 28 families. The most representative families were Cactaceae (18 species), Fabaceae (16 species), Asteraceae (six species), and Agavaceae (five species). Analysis of variance showed highly significant differences between the shrublands in terms of the studied plant attributes. The microphyllous desert shrubland showed the lowest plant density $\left(1,868 \mathrm{~N} \mathrm{ha}^{-1}\right)$ and plant coverage $\left(2,637 \mathrm{~m}^{2} \mathrm{ha}^{-1}\right)$ and the piedmont scrub the highest $(4,512 \mathrm{~N}$ ha and $17,931 \mathrm{~m}^{2} \mathrm{ha}^{-1}$, respectively). With respect to specific richness and the alpha diversity index, the lowest values $\left(S=3.72\right.$ and $H^{\prime}=$ 0.91 , respectively) were presented by the microphyllous desert shrubland, whereas the semithorn shrubland exhibited the highest values $\left(S=11.56\right.$ and $H^{\prime}=2.15$ ). This study provides valuable information about the composition, structure and diversity of shrublands in the state of Nuevo Leon.
\end{abstract}

Key words: piedmont scrub, tamaulipan thornscrub, xerophytic shrub.

Resumen: El objetivo de la presente investigación fue realizar un análisis comparativo de cinco matorrales (matorral subinerme, matorral desértico micrófilo, matorral desértico rosetófilo, matorral submontano, matorral espinoso tamaulipeco), del estado de Nuevo León (noreste de México). Se establecieron 25 sitios de muestreo $\left(100 \mathrm{~m}^{2} ; 125\right.$ en total), en cada matorral estudiado para evaluar la estructura de la vegetación. En cada sitio de muestreo se evaluó la densidad $\left(\mathrm{N} \mathrm{ha}^{-1}\right)$, cobertura de copa $\left(\mathrm{m}^{2}\right.$ ha $\left.{ }^{-1}\right)$, riqueza específica $(S)$, y la diversidad alfa $\left(H^{\prime}\right)$. Se realizó un análisis de varianza para determinar si existían diferencias significativas entre las cinco áreas evaluadas. En los cinco matorrales se registraron 85 especies de plantas vasculares, 65 géneros y 28 familias. Las familias más representativas fueron Cactaceae (18 especies), Fabaceae (16 especies), Asteraceae (seis especies) y Agavaceae (cinco especies). El análisis de varianza mostró diferencias significativas. El matorral desértico micrófilo reveló los valores más bajos en términos de densidad de plantas $\left(1,868 \mathrm{~N} \mathrm{ha}^{-1}\right)$ y cobertura de copa $\left(2,637 \mathrm{~m}^{2} \mathrm{ha}^{-1}\right)$, mientras que el matorral submontano los más altos $\left(4,512 \mathrm{~N} \mathrm{ha}^{-1}\right.$ y $17,931 \mathrm{~m}^{2} \mathrm{ha}^{-1}$, respectivamente). Respecto a la riqueza específica y la diversidad, las cifras más bajas $\left(S=3.72\right.$ y $H^{\prime}=0.91$, respectivamente) corresponden al matorral desértico micrófilo, mientras que el matorral subinerme exhibió los valores más altos $\left(S=11.56\right.$ y $H^{\prime}=2.15$, respectivamente).

Palabras clave: matorral submontano, matorral tamaulipeco, matorral xerófilo.

I n Mexico, shrublands (xerophytic shrub vegetation, some of which are known as matorral) are the most important floristic communities, as they cover an area of approximately $800,000 \mathrm{~km}^{2}$, representing approximately $40 \%$ of coun- try total area (Rzedowski, 1978). The wide range of abiotic conditions in terms of climate and soil types allow shrublands to display different biological forms, species compositions, and floristic diversities (Muller, 1939). According 
to the classification of INEGI (2005), fourteen community types are found in Mexico, most of which are widespread in the north of the country. In the state of Nuevo Leon (northeastern Mexico), the following five shrubland community groups are registered: semithorny shrubland (SS), microphyllous desert shrubland (MDS), rosetophyllous desert shrubland (RDS), piedmont scrub (PS), and tamaulipan thornscrub (TT).

In northeastern Mexico, shrublands have provided multiple ecosystem services and have been utilized as sources of forage for livestock and wildlife, fuelwood, charcoal, timber for construction, fence materials and medicinal herbs, in addition to being subjected to agroforestry practices (Reid et al., 1990; Foroughbakhch et al., 2005. Because these shrublands are a natural resource that warrants conservation and proper management measures from an ecological and economic perspective to maintain and even promote these ecosystem services, there is a need to understand their structures and floristic traits at all levels.

In the state of Nuevo Leon, during the last ten years, a number of studies have been undertaken in different types of shrubland communities. These studies have been focused on the composition (Estrada et al., 2004, 2005, GonzálezRodríguez et al., 2010), structure (Reid et al., 1990; GarcíaHernández and Jurado, 2008; Canizales-Velázquez et al., 2009; González-Rodríguez et al., 2010; Molina-Guerra et al., 2013; Jiménez et al., 2012, 2013), distribution (Estrada et al., 2010), and diversity of plant species (Espinoza-Bretado and Návar, 2005; Alanís et al., 2008; Villarreal-Quintanilla and Estrada-Castillón, 2008; Jiménez-Pérez et al., 2009; Canizales-Velázquez et al., 2009; Estrada et al., 2010, Estrada-Castillón et al., 2012; Jiménez et al., 2013). However, there have been few studies (Briones and Villarreal, 2001; Encina-Domínguez et al., 2013) aimed at comparing different types of shrublands in terms of their physiognomy, floristic composition, and diversity between highlands (Altiplano) and lowlands (Planicie Costera del Golfo), and there are no available studies that address and examine the relationships between structural indicator traits and diversity values in the shrublands of northeastern Mexico. Thus, the aim of this study was to conduct a comprehensive and comparative analysis, at the plant community level, of the five most common types of shrublands found in the state of Nuevo Leon with respect to their structure, including their plant density $\left(\mathrm{N} \mathrm{ha}^{-1}\right)$, plant coverage $\left(\mathrm{m}^{2} \mathrm{ha}^{-1}\right)$, specific richness $(S)$, and alpha diversity $\left(H^{\prime}\right)$.

\section{Materials and methods}

Study area. The study was carried out in the shrublands of the center of the state of Nuevo Leon, in northeastern Mexico $\left(25^{\circ} 58^{\prime}\right.$ to $25^{\circ} 34^{\prime} \mathrm{N}, 100^{\circ} 35^{\prime}$ to $100^{\circ} 16^{\prime} \mathrm{W}$ ), encompassing municipalities of the Monterrey metropolitan area, including Salinas Victoria (tamaulipan thornscrub, TT), Monterrey (semithorny shrubland, SS, and piedmont scrub PS), Garcia (microphyllous desert shrubland, MDS), and Santa Catarina (rosetophyllous desert shrubland, RDS; Figure 1). Table 1 presents some physical and climatic variables as a description of the studied areas.

Sampling. In the years 2010 and 2011, 25 sampling plots with sizes of $100 \mathrm{~m}^{2}(10 \times 10 \mathrm{~m})$ were established in each shrubland, resulting in a total of 125 plots for characterizing the vegetation. The distribution of the sampling plots

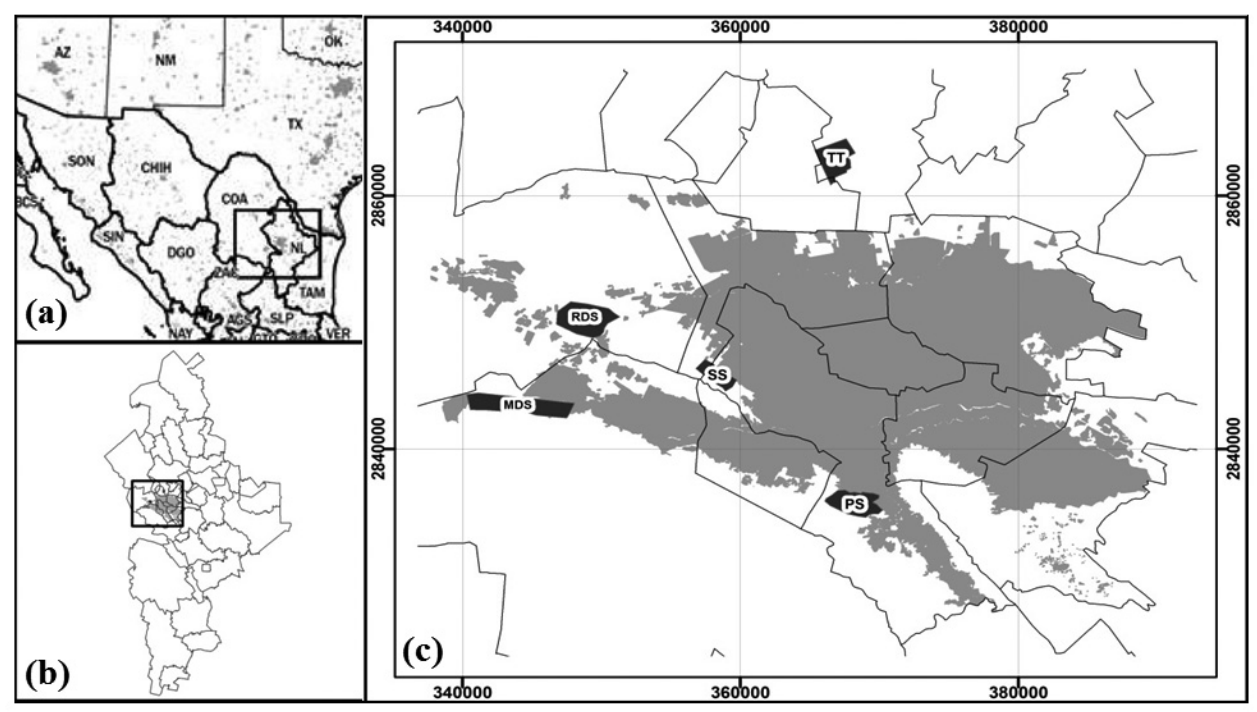

Figure 1. Location of the study sites. A) North of Mexico and south of the USA, B) In the state of Nuevo Leon, northeastern Mexico, and C) In municipalities of the Monterrey metropolitan area, in addition to the areas evaluated. The shaded areas represent urban areas. TT, tamaulipan thornscrub; SS, semithorn shrubland; PS, piedmont scrub; MDS, microphyllous desert shrubland; RDS, rosetophyllous desert shrubland. 
Table 1. Physical and climatic variables of the evaluated areas (Anonymous, 1981).

\begin{tabular}{|c|c|c|c|c|c|}
\hline Vegetation & $\begin{array}{l}\text { Tamaulipan } \\
\text { thornscrub }\end{array}$ & $\begin{array}{l}\text { Semithorn } \\
\text { shrubland }\end{array}$ & $\begin{array}{l}\text { Microphyllous } \\
\text { desert shrubland }\end{array}$ & Piedmont scrub & $\begin{array}{l}\text { Rosetophyllous } \\
\text { desert shrubland }\end{array}$ \\
\hline Abbreviation & TT & SS & MDS & PS & RDS \\
\hline Coordinates & $\begin{array}{l}25^{\circ} 54^{\prime} 48^{\prime \prime} \mathrm{N} \\
100^{\circ} 18^{\prime} 41^{\prime \prime} \mathrm{O}\end{array}$ & $\begin{array}{l}25^{\circ} 43^{\prime} 07^{\prime \prime} \mathrm{N} \\
100^{\circ} 24^{\prime} 28^{\prime \prime} \mathrm{O}\end{array}$ & $\begin{array}{c}25^{\circ} 46^{\prime} 09^{\prime \prime} \mathrm{N} \\
100^{\circ} 30^{\prime} 53^{\prime \prime} \mathrm{O}\end{array}$ & $\begin{array}{l}25^{\circ} 36^{\prime} 18^{\prime \prime} \mathrm{N} \\
100^{\circ} 17^{\prime} 47^{\prime \prime} \mathrm{O}\end{array}$ & $\begin{array}{l}25^{\circ} 41^{\prime} 37^{\prime \prime} \mathrm{N} \\
100^{\circ} 34^{\prime} 06^{\prime \prime} \mathrm{O}\end{array}$ \\
\hline $\begin{array}{l}\text { Altitude (meters } \\
\text { above sea level) }\end{array}$ & 480 & 850 & 930 & 660 & 640 \\
\hline $\begin{array}{c}\text { Mean annual } \\
\text { temperature }\left({ }^{\circ} \mathrm{C}\right)\end{array}$ & 20 to 22 & 20 to 22 & 20 to 22 & 18 to 20 & 18 to 20 \\
\hline $\begin{array}{c}\text { Mean annual } \\
\text { precipitation }(\mathrm{mm})\end{array}$ & 400 to 600 & 300 to 600 & 300 to 400 & 400 to 600 & 125 to 300 \\
\hline Soil type & luvic xerosols & lithosols, rendzinas & luvic lithosols & lithosols, vertisols & regosols, xerosols \\
\hline
\end{tabular}

was systematic, with a distance of $50 \mathrm{~m}$ between them. According to the species-area curve, community SS presented a minimum of 25 sites, while the other communities displayed a fewer sampling plots. For the statistical analysis, we established the same number of sampling plots for each community.

A square shape was used for each plot because this shape made it easier to layout and measure the structural attributes of vegetation in the studied sites (Canizales-Velázquez et al., 2009). In each sampling plot, an inventory of all of the woody species was performed, including measurements such as determination of the plant coverage $\left(\mathrm{m}^{2}\right)$ and stem diameter $(\mathrm{cm})$ at $10 \mathrm{~cm}$ above the soil surface $\left(d_{0.10} \geq\right.$ $1 \mathrm{~cm}$ ), which represents a standard measurement used for woody species in TT (Alanís et al., 2008; Jiménez-Pérez et al., 2009).

Analysis. The absolute abundance and dominant species were calculated. The absolute abundance $(A)$ is defined as $A_{i}$ $=N_{i} S^{-1}$, where $A_{i}$ is the absolute abundance of species $i ; N_{i}$ is the number of individuals of species $i$; and $S$ is the sampled area (ha). To estimate dominance $(D)$, the plant coverage $\left(\mathrm{m}^{2} \mathrm{ha}^{-1}\right)$ of each individual was determined. The absolute dominance is estimated as $D_{i}=A b_{i} S^{-1}$, where $D_{i}$ is the absolute dominance of species $i$; $A b_{i}$ is the plant coverage of species $i$; and $S$ is the sampled area (ha) (Mueller-Dombois and Ellemberg, 1974; Mostacedo and Fredericksen, 2000). Species richness $(S)$ was quantified as the total number of species at each site. The index of diversity was assessed for each site as follows (Shannon, 1948):

$$
\begin{gathered}
H^{\prime}=-\sum_{i=1}^{\mathrm{S}} p_{\mathrm{i}} * \ln \left(p_{\mathrm{i}}\right) \\
p_{\mathrm{i}}=n_{i} N
\end{gathered}
$$

where $H^{\prime}$ is the Shannon index of diversity; $\ln$ is the natural logarithm; $p_{i}$ is the proportion of species $i ; n_{i}$ is the number of individuals of species $i$; and $N$ is the total number of individuals.
Statistical analyses of density, plant coverage, species richness, and diversity were performed following the assumptions of a normal distribution and equality of variances using the one-way ANOVA, or failing that, an equivalent nonparametric test, the Kruskal-Wallis test, under the null hypothesis of equal means or medians. When differences were observed, complementary tests, such as Tukey and Nemenyi ranges (Wheater and Cook, 2005), were used for multiple comparisons. The floristic composition of the scrubs was explored through Bray-Curtis ordination analysis of (Bray and Curtis, 1957). The results are presented in a dendrogram, thereby revealing the similarity among the evaluated scrubs. Statistical analyses were performed using the software package BioDiversity Professional Version 2 (McAleece, et al., 1997).

\section{Results}

A total of 85 plant species were registered in the five studied communities, which belonged to 65 genera and 28 families (Appendix 1). The most representative families were Cactaceae (18 species) and Fabaceae (16 species), followed by Asteraceae (six species) and Agavaceae (five species). RDS showed the greatest number of plant species (48), followed by PS, SS, and TT, with 34, 33, and 30 species, respectively. These four scrub plant communities exhibited a similar number of families (between 18 and 19). The MDS community displayed the lowest number of plant species (15) and families (9). Two of the recorded plant species (Echinocereus poselgeri and Lophophora williamsii, Cactaceae) are considered protected under the official norm list (NOM059-SEMARNAT-2010) of the Mexican government for species with a protected status (SEMARNAT, 2010).

The abundance of scrub showed highly significant differences among communities $(F=13.015, d f=4, P<0.001$; Figure 2A). The MDS plant community was the type of scrub presenting the lowest abundance $\left(1,868 \mathrm{~N} \mathrm{ha}^{-1}\right)$, while the other four plant communities showed similar abundances, with values ranging from 3,732 (SS) to 4,512 $\mathrm{N} \mathrm{ha}^{-1}$ (PS). 

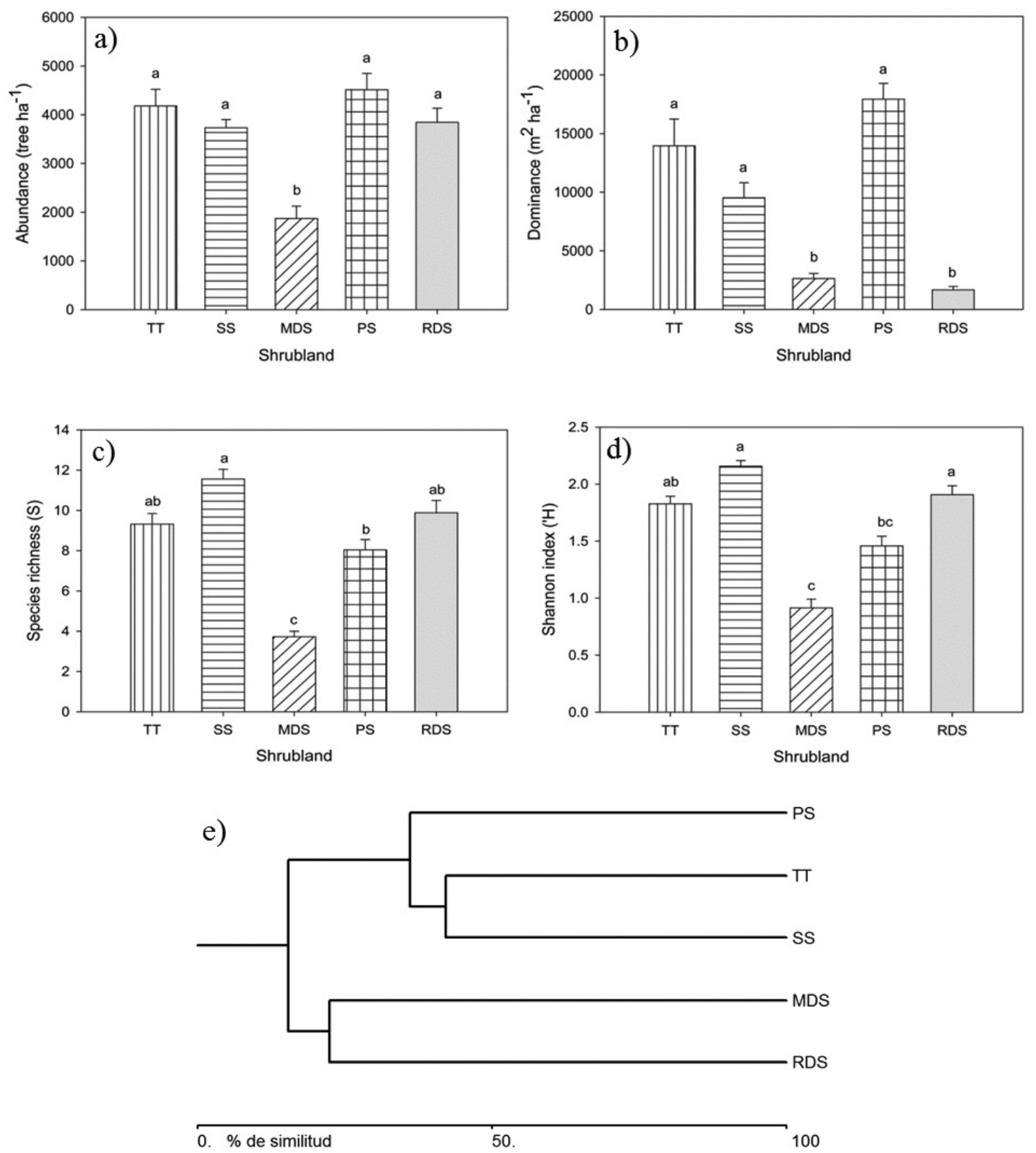

Figure 2. A) Abundance (tree ha-1) of the evaluated communities, B) Dominance $\left(\mathrm{m}^{2} \mathrm{ha}^{-1}\right)$ of the evaluated communities, C) Species richness $(S)$ of the evaluated communities, D) Shannon index $\left(H^{\prime}\right)$ of the evaluated communities; E) Dendrogram of the similarity matrix according to Bray-Curtis ordination for the evaluated vegetation. TT, tamaulipan thornscrub; SS, semithorn shrubland; PS, piedmont scrub; MDS, microphyllous desert shrubland; RDS, rosetophyllous desert shrubland. Means $( \pm$ standard error, $\mathrm{n}=25)$ followed by different letters $(\mathrm{a}, \mathrm{b}, \mathrm{c})$ show significant differences at $P=0.05$.

Significant differences in the dominant species present were observed among the five studied scrub types $\left(x^{2}\right.$ $=88.46, d f=4, P<0.001$; Figure 2B). The desert plant communities exhibited lower plant coverage values than the other community types, but similar values were obtained between them (1,671 and 2,637 $\mathrm{m}^{2} \mathrm{ha}^{-1}$ for RDS and MDS, respectively). In contrast, scrub communities SS, TT, and PS displayed higher, comparable values of 9,523, 13,960, and $17,931 \mathrm{~m}^{2} \mathrm{ha}^{-1}$, respectively, but these values were significantly different. Plant species richness $(S)$ differed significantly $\left(x^{2}=61.88, d f=4, P<0.001\right)$ among the evaluated areas (Figure 2C). The scrub type that presented the lowest richness values was MDS $(S=3.72)$, followed by PS ( $S=$ 8.04). In contrast, plant communities RDS ( $\mathrm{S}=8.50)$, TT $(\mathrm{S}=9.32)$, and SS $(S=11.56)$ showed higher and similar richness values. 
The Shannon diversity values also differed $\left(x^{2}=71.64\right.$, $d f=4, P<0.001$ ) among the evaluated areas (Figure 2D). Scrub communities MDS and PS exhibited the lowest Shannon diversities, presenting values of 0.91 nats and 1.46 nats, respectively, while plant communities RDS and SS attained higher Shannon diversity values of 1.90 nats and 2.15 nats, respectively.

A large number of species (44, representing 51.8\% of the total species present) were recorded only in one specific type of shrubland, and up to 14 were observed in only two different types. Thus, the plant communities showed lower similarity compared with the plant composition. The scrub types that displayed the highest similarities were TT and SS, presenting a value of $42 \%$, followed by PS with SS and TT, with 36\%, and MDS with RDS, with 22\% (Figure 2E).

\section{Discussion}

The species richness (85) registered in the present study area was higher compared with a previous study conducted in piedmont scrub, which recorded 52 species (CanizalesVelázquez et al., 2009), and a study conducted in tamaulipan thornscrub, identifying 27 plant species (Jiménez-Pérez et al., 2009). In this study, RDS was the community that showed the highest plant diversity, due to the frequent presence of cactus species, two of which are under the special protection risk category (Appendix 1). Other reports have shown that plants belonging to the Agavaceae and Cactaceae families are important components of the rosetophyllous vegetation (Rzedowski, 1978; Martorell and Ezcurra, 2002).

Among all of the plant families registered in this study, the Fabaceace played a particularly important role within the floristic composition of the scrub, particularly in TT and $\mathrm{PS}$, which agrees with previous studies in this region (Canizales-Velázquez et al., 2009; Jiménez-Pérez et al., 2009; González-Rodríguez et al., 2010). However, our findings disagree with observations reported by Huerta-Martínez and García-Moya (2004) in that in the PS plant community, the most representative family was Cactaceae, with 18 species, followed by the Fabaceae, with nine species. The MDS vegetation showed a similar number of Cactaceae and Fabaceace species, which presented three species each; these findings disagree with those of Huerta-Martínez and García-Moya (2004) who documented a large number (33) of cactus species in MDS. An explanation for this difference is that by Huerta-Martínez and García-Moya (2004) evaluated an area with edaphic and altitudinal variations, which caused a high species richness. With respect to the RDS vegetation, 17 plant species belonging to Cactaceae were found, which agrees with studies conducted by Huerta-Martínez and García-Moya (2004) and Carmona-Lara et al. (2008).

Celtis pallida was the only species identified in all five types of shrublands, while Guaiacum angustifolium and
Echinocereus stramineus were absent only from PS; Leucophyllum frutescens, Karwinskia humboldtiana, Forestiera angustifolia, and Opuntia engelmannii were absent only from MDS; and Cordia boissieri was absent only from RDS. These generalist species contrast with most of the recorded species (44 out of 85 ), which are specific to a unique type of shrubland. As mentioned previously, this situation is the main factor conditioning the low similarity values between these five shrubland communities in northeast Mexico.

Abundance and dominant of species. The MDS community showed minimum abundance and was significantly different from the other studied scrublands. The most abundant species were Gutierrezia sarothrae $\left(146 \mathrm{~N} \mathrm{ha}^{-1}\right)$, Prosopis glandulosa $\left(92 \mathrm{~N} \mathrm{ha}^{-1}\right)$, Castela erecta subsp. texana $\left(75 \mathrm{~N} \mathrm{ha}^{-1}\right)$, and Agave lecheguilla $\left(56 \mathrm{~N} \mathrm{ha}^{-1}\right)$. According to the results reported by Huerta-Martínez and García-Moya (2004), only $P$. glandulosa was registered as a representative species for this community. In contrast, the remaining plant communities were composed of large number of individuals, with higher abundance and similarity being observed among these communities.

With respect to dominance, it was clear that vegetation types such as TT, PS, and SS showed a higher dominance value with respect to the other plant communities, due in part to the tree and shrub species they harbor, such as Celtis spp., Cordia boissieri, Acacia spp., Havardia pallens, and Zanthoxylum fagara, among others. In contrast, the shrublands with lower dominance are characterized by an abundance of smaller species, particularly the RDS plant community $\left(1,671 \mathrm{~m}^{2} \mathrm{ha}^{-1}\right)$, which displayed the lowest dominance value among the five studied plant communities. RDS showed the greatest number of species belonging to the Cactaceae and Agavaceae, as it was composed of numerous cactus species with rosette-like leaves, with or without thorns, which were generally acaulescent. Carmona-Lara et al. (2008) documented 30 cactus species in a region of the municipality of Garcia, Nuevo Leon, within the Sierra Corral de Los Bandidos Natural Protected Area in Mexico; in this study, 15 cactus species were registered, 13 of which were recorded in the natural protected area. Following the RDS plant vegetation type in terms of dominance, a value of 2,637 $\mathrm{m}^{2} \mathrm{ha}^{-1}$ was observed for the MDS. Hernández et al. (1998) documented a lower dominance value $\left(1,500 \mathrm{~m}^{2}\right.$ $\left.\mathrm{ha}^{-1}\right)$ compared with the present study. These differences are related to lower plant diversity, which suggests that the MDS plant vegetation type is composed of smaller number of species that are consequently the dominant species. In this study, MDS showed the lowest plant species richness.

Species diversity and richness. The MDS community showed 15 plant species and a Shannon diversity index of 0.91 nats, thus representing the community with the lowest species richness and diversity values. These results are in 
agreement with the findings of Huerta-Martínez and GarcíaMoya (2004), who registered the lowest diversity index value ( $H^{\prime}=1.07$ nats) but the highest plant richness ( 37 species) in MDS plant community. These results showed that the MDS plant community presented the lowest diversity value due to its lower species richness and higher abundance. In contrast, the highest richness was observed in the RDS community, where 48 species were recorded, followed by the PS and SS communities, with 34 and 33 plant species, respectively. These results are in agreement with the observations made by Huerta-Martínez and García-Moya (2004), who recognized the highest plant richness in this type of vegetation. In a study carried out by Carmona-Lara et al. (2008), 45 and 18 species were recorded in two RDS research sites, while Estrada et al. (2005) reported values in the north of Nuevo Leon state of approximately 48 and 52 species for PS and SS, respectively, which were higher than the values obtained in the present study. In another study, Canizales-Velázquez et al. (2009) registered a richness value of 52 species for a PS plant community. This value is slightly higher than the value observed in the present work; in regard to the plant richness of TT, this community presented the highest richness value (30 species) among the five studied communities. Jiménez-Pérez et al. (2009) reported richness values of 24 and 19 plant species in a study conducted at two sites harboring TT vegetation. These differences could be attributed to previous intense management practices, which diminished the number of species (Pausas and Austin, 2001, Alanís et al., 2013). These results showed that these shrublands exhibit high species richness, as Fabaceae was a representative group in the three communities with a large number of species. In agreement with other studies, this family was the most representative in the Center of Nuevo Leon state (Estrada et al., 2004). The RDS plant community showed the highest species richness due to the presence of a large number of species from the Cactaceae.

The SS plant community showed the highest diversity value (2.15 nats), followed by RDS (1.90). In a study conducted by Huerta-Martínez and Garcia-Moya (2004), the PS vegetation type was found to show the highest diversity index $\left(H^{\prime}=1.88\right.$ nats), followed by RDS $\left(H^{\prime}=1.83\right.$ nats). It should be noted that the results observed by these authors in PS and MDS are similar to the findings of this study. For the northwest region of Nuevo Leon, Carmona-Lara et al. (2008) reported diversity index values between 2.86 nats and 2.36 nats in RDS. With respect to the PS vegetation type, it showed a diversity index of 1.46 nats, which was much lower than the index of 3.0 nats documented by $\mathrm{Ca}-$ nizales-Velázquez et al. (2009). Accordingly, these authors also found a higher richness with respect to the present study. A diversity index value of 1.80 nats was observed in the present study in a TT community, whereas Jiménez-Pérez et al. (2009) documented diversity index values in the range of 2.10 to 2.24 in abandoned land areas with a history of farming and grazing. Studies conducted by González-Rodríguez et al. (2010) at three sites that had not undergone any apparent land use change in northeastern Nuevo Leon revealed diversity index values in the range of 2.4 to 2.8 . These results showed that TT plant community presents the highest diversity value, associated with a high species richness due to the lack of predominance of one or more species.

As observed by Huerta-Martínez and García-Moya (2004), as well as Villarreal-Quintanilla and Encina-Domínguez (2005), the RDS plant community type is listed as the type of shrubland with the greatest number of plant species in the official norm list (NOM-059-SEMARNAT-2010) of the Mexican government for taxa at risk, with two species. MDS presents just one plant species in this list. In contrast, in a natural protected area of Nuevo Leon state next to the study area, Carmona-Lara et al. (2008) observed eight species comprised in the official norm list, all of which belonged to the Cactaceae.

According to Mas and Pérez-Vega (2005), xerophytic shrublands account for approximately $11 \%$ of the total surface area $\left(58,129 \mathrm{~km}^{2}\right)$ of the National System of Natural Protected Areas. Thus, approximately $6,394 \mathrm{~km}^{2}$ of these lands belong to some category of natural protected area in Mexico. These lands encompass approximately $6.9 \%$ of the surface area of the RDS vegetation type $\left(7,341 \mathrm{~km}^{2}\right)$ in the National System of Natural Protected Areas. Which also encompass $5.6 \%$ of the MDS surface area $\left(11,548 \mathrm{~km}^{2}\right)$ and $5.3 \%$ of the PS surface area $\left(1,471 \mathrm{~km}^{2}\right)$ in the National System of Natural Protected Areas. The percentage is calculated with respect to the total area of each vegetation type.

This situation reflects the great value of conserving these types of plant communities based on the threatened species found within them and the low dominance observed in natural protected areas. Moreover, these communities are characterized by high vulnerability and fragility of their vegetation due to the serious decrease in their surface area in the last decade, even though their plant communities have been extensively used for various purposes, such as animal feed resources consumed by range livestock and wildlife, charcoal, fuelwood, timber for construction, fiber, fence materials, foodstuffs, and medicinal herbs (Alanís and Foroughbakhch, 2008). The most important threats to these plant communities types are activities leading to land use changes, which have resulted in habitat loss and fragmentation, a diminished cover and composition of vegetation, and growth of urban areas due to human activities.

\section{Acknowledgements}

We thankfully acknowledge all of the technicians involved for their outstanding technical field assistance and to two anonymous reviewers. 


\section{Literature cited}

Anonymous. 1981. Síntesis geográfica del estado de Nuevo León. Instituto Nacional de Estadística Geografía e Informática. México D.F. 170 pp.

Alanís F.G.J. and Foroughbakhch R. 2008. Antiguos grupos étnicos en el norte de Nuevo León y el uso de flora nativa. Ciencia UANL 11:140-144.

Alanís R.E., Jiménez P.J., Aguirre C.O., Treviño G.E., Jurado Y.E. and González T.M. 2008. Efecto del uso del suelo en la fitodiversidad del matorral espinoso tamaulipeco. Ciencia UANL 11:56-62.

Alanís R.E., Jiménez P.J., González T.M.A., Yerana Y.J.I., Cuellar R.G. and Mora-Olivo A. 2013. Análisis de la vegetación secundaria del matorral espinoso tamaulipeco, México. Phyton International Journal of Experimental Botany 82:185-191.

Bray J.R. and Curtis J.T. 1957. An ordination of the upland forest communities of Southern Wisconsin. Ecological Monographs 27:325-349.

Briones O. and Villarreal Q.J.A. 2001. Vegetación y flora de un ecotono entre las provincias del Altiplano y la Planicie Costera del Noreste de México. Acta Botanica Mexicana 55:39-67.

Canizales-Velázquez P.A., Alanís-Rodríguez E., Aranda-Ramos R., Mata-Balderas J.M., Jiménez-Pérez J., Alanís-Flores G., Uvalle-Sauceda J.I. and Ruiz-Bautista M.G. 2009. Caracterización estructural del matorral submontano de la Sierra Madre Oriental, Nuevo León, México. Revista Chapingo Serie Ciencias Forestales y del Ambiente 15:115-120.

Carmona-Lara M.P., Foroughbakhch R., Flores-Valdés A., Alvarado M.A. and Guzmán-Lucio M.A. 2008. Flora cactológica y especies asociadas en el área natural protegida Sierra Corral de los Bandidos, Nuevo León, México. Revista Mexicana de Biodiversidad 79:307-323.

Encina-Domínguez J.A., Meave J.A. and Zárate-Lupercio A. 2013. Structure and woody species diversity of the Dasylirion cedrosanum (Nolinaceae) rosette scrub of central and southern Coahuila State, Mexico. Botanical Sciences 91:335-347.

Espinoza-Bretado R. and Návar J. 2005. Producción de biomasa, diversidad y ecología de especies en un gradiente de productividad en el matorral espinoso tamaulipeco del nordeste de México. Revista Chapingo Serie Ciencias Forestales y del Ambiente 11:25-31.

Estrada C.E., Villarreal Q.J.A. and Jurado E. 2005. Leguminosas del norte del estado de Nuevo León, México. Acta Botanica Mexicana 73:1-18.

Estrada C.E., Yen M.C., Delgado S.A. and Villarreal Q.J.A. 2004. Leguminosas del centro del estado de Nuevo León, México. Anales del Instituto de Biología, Universidad Nacional Autónoma de México, Serie Botánica 75:73-85.

Estrada C.E., Delgado-Salinas A., Villarreal Q.J.A., Scott M.L., Cantú A.C. and García P.J. 2010. Diversity and distributional patterns of legumes in Northeastern Mexico. The Southwestern Naturalist 55:426-433.

Estrada-Castillón E., Villarreal-Quintanilla J.A., Jurado-Ybarra E., Cantú-Ayala C., García-Aranda M.A., Sánchez-Salas J., Jiménez-Pérez J. and Pando-Moreno M. 2012. Clasificación, estructura y diversidad del matorral submontano adyacente a la planicie costera del Golfo Norte en el Noreste de México. Botanical Sciences 90:37-52.

Foroughbakhch R., Reyes G., Alvarado-Vázquez M.A., Hernán-
dez-Piñero J. and Rocha-Estrada A. 2005. Use of quantitative methods to determine leaf biomass on 15 woody shrub species in northeastern Mexico. Forest Ecology and Management 216:359-366.

García-Hernández J. and Jurado E. 2008. Caracterización del matorral con condiciones prístinas en Linares N. L., México. $R a$ Ximhai 4:1-21.

González-Rodríguez H., Ramírez-Lozano R.G., Cantú-Silva I., Gómez-Meza M.V. and Uvalle-Sauceda J.I. 2010. Composición y estructura de la vegetación en tres sitios del estado de Nuevo León, México. Polibotánica 29:91-106.

Hernández C.C., Alanís F.G., Favela L.S. and Ledezma M.A. 1998. Caracterización de la vegetación del Desierto Sonorense en un Área del Municipio de Pitiquito, Sonora, México. In: Gottfried G.J., Edminster C.B. and Dillon M.C. Comps. Cross Border Waters: Fragile Treasures for the 21 $1^{\text {st }}$ Century: Ninth U.S./ Mexico Border States Conference on Recreation, Parks, and Wildlife, pp. 91-99, United States Department of Agriculture, Forest Service, Rocky Mountain Research Station, Colorado.

Huerta-Martínez F.M. and García-Moya E. 2004. Diversidad de especies perennes y su relación con el ambiente en un área semiárida del centro de México: implicaciones para la conservación. Interciencia 29:435-441.

INEGI. Instituto Nacional de Estadística, Geografía e Informática. 2005. Guía para la Interpretación de la Cartografía: Uso de Suelo y Vegetación. Instituto Nacional de Estadística, Geografía e Informática, Aguascalientes.

Jiménez-Pérez J., Alanís-Rodríguez E., Aguirre-Calderón O., Pando-Moreno M. and González-Tagle M. 2009. Análisis sobre el efecto del uso del suelo en la diversidad estructural del matorral espinoso tamaulipeco. Madera y Bosques 15:5-20.

Jiménez P.J., Alanís R.E., González T.M.A., Aguirre C.O.A. and Treviño G.E.J. 2013. Characterizing regeneration of woody species in areas with different land-history tenure in the tamaulipan thornscrub, Mexico. The Southwestern Naturalist 58:299-304.

Jiménez P.J., Alanís R.E., Ruiz G.J.L., González T.M.A., Yerena Y.J.I. and Alanís F.G.J. 2012. Diversidad de la regeneración leñosa del matorral espinoso tamaulipeco con historial agrícola en el noreste de México. Ciencia UANL 15:66-71.

Martorell C. and Ezcurra E. 2002. Rosette scrub occurrence and fog availability in arid mountains of Mexico. Journal of Vegetation Science 13:651-662.

Mas J.F. and Pérez-Vega B.A. 2005. La representatividad del Sistema Nacional de Áreas Naturales Protegidas (SINAP). Gaceta Ecológica 74:5-14.

McAleece, N., Lambshead, J., Paterson, G. L. J., and Gage, J. D. 1997. BioDiversity pro, Version 2. The Natural History Museum, London, and The Scottish Association of Marine Science, Oban, Scotland.

Molina-Guerra V.M., Pando-Moreno M., Alanís-Rodríguez E., Canizales-Velázquez P.A., González R.H. and Jiménez-Pérez J. 2013. Composición y diversidad vegetal de dos sistemas de pastoreo en el matorral espinoso tamaulipeco del Noreste de México. Revista Mexicana de Ciencias Pecuarias 4:361-371.

Mostacedo B. and Fredericksen T.S. 2000. Manual de Métodos Básicos de Muestreo y Análisis en Ecología Vegetal. Proyecto de Manejo Forestal Sostenible. Santa Cruz de la Sierra.

Muller C.H. 1939. Relations of the vegetation and climatic types in Nuevo Leon, Mexico. American Midland Naturalist 21:687729. 
Mueller-Dombois D. and Ellemberg H. 1974. Aims and Methods of Vegetation Ecology. John Wiley \& Sons, New York.

Pausas J.G. and Austin M.P. 2001. Patterns of plant species richness in relation to different environments: An appraisal. Journal of Vegetation Science 12:153-166.

Reid N., Marroquín J. and Beyer-Münzel P. 1990. Utilization of shrubs and trees for browse, fuelwood and timber in the Tamaulipan thornscrub, northeastern Mexico. Forest Ecology and Management 36:61-79.

Reid N., Smith D.M., Beyer-Münzell P. and Marroquín J. 1990. Floristic and structural variation in the Tamaulipan thornscrub, northeastern Mexico. Journal of Vegetation Science 1:529-538.

Rzedowski J. 1978. Vegetación de México. Limusa, México, D.F.

SEMARNAT. Secretaría de Medio Ambiente y Recursos Naturales. 2010. Norma Oficial Mexicana NOM-059-SEMARNAT-2010. Protección ambiental-Especies nativas de México de flora y fauna silvestres-Categorías de riesgo y especificaciones para su inclusión, exclusión o cambio-Lista de especies en riesgo.

Shannon C.E. 1948. A mathematical theory of communication. The Bell System Technical Journal 27:379-423, 623-656.

Tropicos. 2014. Tropicos.org. Missouri Botanical Garden. <http:// www.tropicos.org/Home.aspx> (accessed April 11, 2014).

Villarreal-Quintanilla J.A. and Encina-Domínguez J.A. 2005. Plantas vasculares endémicas de Coahuila y algunas áreas adyacentes. Acta Botanica Mexicana 70:1-46.

Villarreal-Quintanilla J.A. y Estrada-Castillón A.E. 2008. Flora de Nuevo León. Listados Florísticos de México XXIV. Instituto de Biología, Universidad Nacional Autónoma de México, México, D.F.

Wheater C. P. and Cook P.A. 2005. Using Statistics to understand the environment. Routledge, Taylor \& Francis e-Library. $<$ http://enforester.persiangig.com/.70kkOuSdkE/using\%20stati stics $\% 20$ to $\% 20$ understand $\% 20$ the $\% 20$ environment.pdf $>$ web page visited on 2015 .

Received: March 5th 2014

Accepted: June 30th 2014 
Appendix 1. Checklist of the plant species and densities $\left(\mathrm{N} \mathrm{ha}^{-1}\right)$ registered in the study area. RDS, rosetophyllous desert shrubland; SS, semithorn shrubland; MDS, microphyllous desert shrubland; PS, piedmont scrub; TT, tamaulipan thornscrub. SP: Special Protection. Nomenclature: Tropicos (2014).

\begin{tabular}{lllllll}
\hline Plant species & RDS & SS & MDS & PS & TT & NOM-059 \\
\hline
\end{tabular}

\section{Agavaceae}

Agave americana L.

Agave lechuguilla Torr.

Agave striata Zucc.

Dasylirion texanum Scheele

Yucca filifera Chabaud

\section{Amaranthaceae}

Atriplex canescens (Pursh) Nutt.

\section{Anacardiaceae}

Rhus microphylla Engelm.

\section{Asteraceae}

Artemisia ludoviciana Nutt.

Gutierrezia microcephala (DC.) A.Gray

Gymnosperma glutinosum (Spreng.) Less.

Parthenium argentatum A.Gray

Parthenium incanum Kunth

Viguiera stenoloba S.F.Blake

\section{Berberidaceae}

Berberis trifoliolata Moric.

\section{Boraginaceae}

Cordia boissieri A.DC.

Ehretia anacua (Teran \& Berl.) I.M.Johnston

\section{Cactaceae}

Coryphantha compacta (Engelm.) Orcutt

Coryphantha difficilis (Quehl) Orcutt

Coryphantha neglecta L.Bremer

Cylindropuntia imbricata (Haw.) F.M.Knuth

Cylindropuntia leptocaulis (DC.) F.M.Knuth.

Echinocactus horizonthalonius Lem.

Echinocereus enneacanthus Engelm.

Echinocereus pectinatus (Scheidw.) Engelm.

Echinocereus stramineus (Engelm.) F.Seitz

Echinocerus poselgeri Lem.

Ferocactus haematacanthus (Muehlenpf.) Britton \& Rose

Lophophora williamsii (Lem. ex Salm-Dyck) J.M.Coult.

Mammillaria melanocentra Poselger

Mammillaria pottsii Scheer ex Salm-Dyck

Neolloydia conoidea (DC.) Britton \& Rose

Opuntia engelmannii Salm-Dyck

Sclerocactus scheeri (Salm-Dyck) N.P.Taylor

Thelocactus bicolor (Galeotti) Britton \& Rose
13

14 


\begin{tabular}{lr}
\hline Plant species & RDS \\
\hline Celastraceae & 34 \\
Mortonia greggii A.Gray & \\
Ebenaceae &
\end{tabular}

Diospyros texana Scheele

Diospyros virginiana L.

\section{Ephedraceae}

Ephedra antisyphilitica Berland. Ex C.A.Mey.

\section{Euphorbiaceae}

Bernardia myricifolia (Scheele) Watts

Croton torreyanus Müll.Arg.

Jatropha dioica Sesse

\section{Fabaceace}

Acacia berlandieri Benth.

Acacia farnesiana (L.) Willd.

Acacia greggii A.Gray

Acacia rigidula Benth.

Caesalpinia mexicana A.Gray

Calliandra conferta Benth

Cercidium macrum I.M.Johnst.

Ebenopsis ebano (Berl.) Britton \& Rose

Eysenhardtia polystachya (Ortega) Sarg.

Eysenhardtia texana Scheele

Leucaena sp.

Mimosa malacophylla A.Gray

Havardia pallens (Benth.) Britton \& Rose

Prosopis glandulosa Torr.

Prosopis leavigata Torr.

Sophora secundiflora (Ortega) DC.

$\begin{array}{cccc}6 & 90 & 13 & \\ & 73 & 8 & 6 \\ 18 & & & \end{array}$

18

32

30

24

9

$4 \quad 24$

9

111

5

37

Fagaceae

Quercus polymorpha Schltdl. \& Cham.

\section{Fouquieriaceae}

Fouquieria splendens Engelm.

\section{Koeberliniaceae}

Koeberlinia spinosa Zucc.

\section{Lythraceae}

Heimia salicifolia (Kunth) Link

60

3

\section{Lauraceae}

Litsea novoleontis Bartlett

\section{Oleaceae}

Forestiera angustifolia Torr.

Fraxinus americana L.

\section{Pinaceae}




\begin{tabular}{|c|c|c|c|c|c|c|}
\hline Plant species & RDS & SS & MDS & PS & TT & NOM-059 \\
\hline \multicolumn{7}{|l|}{ Rhamnaceae } \\
\hline Karwinskia humboldtiana (Willd. ex Roem. \& Schult.) Zucc. & 4 & 17 & & 8 & 26 & \\
\hline Condalia hookeri M.C.Johnst. & 18 & 26 & & 4 & & \\
\hline \multicolumn{7}{|l|}{ Rubiaceae } \\
\hline Randia laetevirens Standl. & & 3 & & 12 & & \\
\hline \multicolumn{7}{|l|}{ Rutaceae } \\
\hline Zanthoxylum fagara (L.) Sarg. & & 53 & & 127 & 95 & \\
\hline \multicolumn{7}{|l|}{ Salicaceae } \\
\hline Neopringlea integrifolia (Hemsl.) S.Watson & & 11 & & & 2 & \\
\hline \multicolumn{7}{|l|}{ Sapindaceae } \\
\hline Sapindus saponaria L. & & & & 2 & & \\
\hline \multicolumn{7}{|l|}{ Sapotaceae } \\
\hline Bumelia lanuginosa (Michx.) Pers. & & 6 & & 12 & & \\
\hline \multicolumn{7}{|l|}{ Scrophulariaceae } \\
\hline Leucophyllum frutescens (Berland.) I.M.Johnst. & 30 & 102 & & 9 & 136 & \\
\hline \multicolumn{7}{|l|}{ Simaroubaceae } \\
\hline Castela texana (Torr. \& A.Gray) Rose & & & 75 & & 26 & \\
\hline \multicolumn{7}{|l|}{ Solanaceae } \\
\hline Capsicum annuum L. & & & & & 1 & \\
\hline Solanum erianthum D.Don & & & & 2 & & \\
\hline \multicolumn{7}{|l|}{ Ulmaceae } \\
\hline Celtis leavigata Willd. & & 11 & & 10 & 55 & \\
\hline Celtis pallida Torr. & 1 & 10 & 1 & 6 & 63 & \\
\hline Ulmus crassifolia Nutt. & & & & 8 & & \\
\hline \multicolumn{7}{|l|}{ Verbenaceae } \\
\hline Aloysia sp. & & & & & 18 & \\
\hline Lantana camara L. & & 44 & & 2 & 118 & \\
\hline \multicolumn{7}{|l|}{ Zygophyllaceae } \\
\hline Guaiacum angustifolia Engelm. & 48 & 10 & 12 & & 31 & \\
\hline Larrea tridentata (Sessé \& Moc. ex DC.) Coville & 29 & & 1 & & & \\
\hline \multicolumn{7}{|l|}{ Without identification } \\
\hline sp.1 & & 7 & & & & \\
\hline sp. 2 & & 3 & & & & \\
\hline Total & 961 & 933 & 448 & 1,137 & 1,045 & 5 \\
\hline
\end{tabular}

